\title{
The insulin response to glucose in patients with pancreatic disease
}

\author{
M. T. MCKIDDIE* \\ M.B., M.R.C.P. \\ Registrar in Medicine
}

\author{
G. C. McBaIN \\ M.B., F.R.C.S. \\ Registrar in Surgery
}

\author{
K. D. BUChanaN \\ M.D., M.R.C.P. \\ Consultant Physician
}

\author{
G. BELL \\ M.B., F.R.C.S. \\ Senior Registrar in Surgery
}

\begin{abstract}
Summary
The insulin response to glucose was studied in twenty-five patients with pancreatic disease, of whom twelve had chronic pancreatitis, five developed glycosuria following an attack of acute pancreatitis and eight had a carcinoma of the pancreas.

A low insulin response was found in subjects with frank diabetes mellitus but in the majority of those with chronic pancreatitis the insulin response was prolonged and of normal degree. This suggests that glucose intolerance in these patients is not due to simple insulin deficiency but may be due to the release of an abnormal insulin or to insulin antagonists.

All eight patients with carcinoma of the pancreas had a low insulin response to glucose.

\section{Introduction}

Impaired glucose tolerance is common in patients with chronic pancreatitis (Chey et al., 1967) and carcinoma of the pancreas (Salmon, 1966). Because of the anatomical relationship of the islets of Langerhans to the exocrine pancreas one might expect that abnormalities of glucose tolerance in these patients would be associated with insulin deficiency. Low plasma insulin levels in 'pancreatic diabetes' were found by Berson \& Yalow (1962) and by Peters et al. (1966). However normal or high fasting insulin levels (Keller et al., 1965) and a variable insulin response to oral glucose (Bank et al., 1968) have also been reported.
\end{abstract}

\section{Materials and methods \\ Patients studied}

Subjects with pancreatic disease: (a) Twelve patients (aged 48-76 years) were studied in whom a

* Present address: Ward 6, Maryfield Hospital, Dundee, DD4 7TL. diagnosis of chronic pancreatitis had been made. Features on which the diagnosis was based were steatorrhoea with normal xylose absorption, pancreatic calcification on X-ray or diagnostic features at laparotomy.

A further five patients, referred to the diabetic clinic with glycosuria, had a well-documented history of acute pancreatitis. Four of these patient had frank symptomatic diabetes, the fifth had chemical diabetes only. One of these patients had require insulin therapy for 1 week only during his attack of acute pancreatitis. The others were untreated at time of study. All five are now well controlled on diet alone. (b) Eight patients were studied in whom a diagnosis of carcinoma of the pancreas was later confirmed at laparotomy or necropsy. All were jaundiced at the time of study.

Control subjects: Eight normal subjects aged 50-65 years and within $10 \%$ of ideal body weight were used as controls.

Standard $50 \mathrm{~g}$ oral glucose tolerance tests were performed after an overnight fast, venous blood being removed fasting and at 30, 60,90 and $120 \mathrm{~min}$ for blood sugar and plasma insulin estimation.

Blood sugar was measured as total reducing substances on the Technicon AutoAnalyzer.

Plasma insulin was assayed by the immunoprecipitation technique of Hales \& Randle (1963) using standards and antisera previously described (Buchanan \& McKiddie, 1967a).

\section{Results}

\section{(a) Patients with pancreatitis}

Of the twelve patients with chronic pancreatitis, three had normal and nine mildly abnormal glucose tolerance (Table 1).

Two of the patients with a normal GTT had a 
TABLE 1. Insulin response to glucose in patients with pancreatitis

\begin{tabular}{|c|c|c|c|c|c|c|c|c|c|c|c|}
\hline \multirow{3}{*}{ Subjects } & \multirow{3}{*}{$\begin{array}{c}\text { Age } \\
\text { (years) }\end{array}$} & \multicolumn{10}{|c|}{ Time after $50 \mathrm{~g}$ oral glucose } \\
\hline & & \multicolumn{5}{|c|}{ Blood sugar $(\mathrm{mg} / 100 \mathrm{ml})$} & \multicolumn{5}{|c|}{ Plasma insulin $(\mu \mathrm{U} / \mathrm{ml})$} \\
\hline & & $0 \mathrm{~min}$ & $30 \mathrm{~min}$ & $60 \mathrm{~min}$ & $90 \mathrm{~min}$ & $120 \mathrm{~min}$ & $0 \mathrm{~min}$ & $30 \mathrm{~min}$ & $60 \mathrm{~min}$ & $90 \mathrm{~min}$ & $120 \mathrm{~min}$ \\
\hline $\begin{array}{l}\text { Normal GTT } \\
1 \\
2 \\
3\end{array}$ & $\begin{array}{l}68 \\
50 \\
54\end{array}$ & $\begin{array}{r}82 \\
84 \\
102\end{array}$ & $\begin{array}{l}155 \\
134 \\
153\end{array}$ & $\begin{array}{l}155 \\
178 \\
116\end{array}$ & $\begin{array}{r}135 \\
104 \\
71\end{array}$ & $\begin{array}{l}92 \\
84 \\
78\end{array}$ & $\begin{array}{r}16 \\
3 \\
66\end{array}$ & $\begin{array}{r}242 \\
35 \\
265\end{array}$ & $\begin{array}{r}230 \\
25 \\
230\end{array}$ & $\begin{array}{r}186 \\
10 \\
90\end{array}$ & $\begin{array}{r}156 \\
8 \\
100\end{array}$ \\
\hline $\begin{array}{l}\text { Abnormal GTT } \\
4 \\
5 \\
6 \\
7 \\
8 \\
9 \\
10 \\
11 \\
12\end{array}$ & $\begin{array}{l}64 \\
54 \\
53 \\
72 \\
59 \\
67 \\
48 \\
72 \\
76\end{array}$ & $\begin{array}{r}96 \\
87 \\
126 \\
97 \\
97 \\
73 \\
120 \\
110 \\
109\end{array}$ & $\begin{array}{l}154 \\
171 \\
220 \\
220 \\
174 \\
130 \\
160 \\
202 \\
148\end{array}$ & $\begin{array}{l}196 \\
199 \\
264 \\
258 \\
181 \\
209 \\
174 \\
248 \\
223\end{array}$ & $\begin{array}{l}208 \\
150 \\
204 \\
150 \\
129 \\
210 \\
168 \\
246 \\
144\end{array}$ & $\begin{array}{r}242 \\
125 \\
170 \\
88 \\
127 \\
144 \\
161 \\
204 \\
73\end{array}$ & $\begin{array}{r}9 \\
30 \\
37 \\
33 \\
42 \\
30 \\
13 \\
21 \\
13\end{array}$ & $\begin{array}{r}105 \\
157 \\
70 \\
71 \\
215 \\
124 \\
20 \\
60 \\
181\end{array}$ & $\begin{array}{r}100 \\
176 \\
108 \\
105 \\
220 \\
197 \\
29 \\
58 \\
72\end{array}$ & $\begin{array}{r}111 \\
106 \\
120 \\
100 \\
166 \\
307 \\
50 \\
62 \\
127\end{array}$ & $\begin{array}{r}132 \\
75 \\
87 \\
51 \\
107 \\
220 \\
45 \\
72 \\
31\end{array}$ \\
\hline $\begin{array}{l}\text { Diabetic } \\
13 \\
14 \\
15 \\
16 \\
17\end{array}$ & $\begin{array}{l}68 \\
54 \\
56 \\
28 \\
70\end{array}$ & $\begin{array}{r}290 \\
119 \\
177 \\
134 \\
88\end{array}$ & $\begin{array}{l}345 \\
190 \\
195 \\
278 \\
164\end{array}$ & $\begin{array}{l}420 \\
260 \\
237 \\
292 \\
156\end{array}$ & $\begin{array}{l}483 \\
284 \\
372 \\
243 \\
154\end{array}$ & $\begin{array}{l}474 \\
253 \\
345 \\
202 \\
136\end{array}$ & $\begin{array}{l}40 \\
20 \\
30 \\
19 \\
15\end{array}$ & $\begin{array}{l}45 \\
30 \\
40 \\
29 \\
74\end{array}$ & $\begin{array}{l}44 \\
42 \\
32 \\
38 \\
60\end{array}$ & $\begin{array}{l}38 \\
57 \\
32 \\
33 \\
79\end{array}$ & $\begin{array}{l}41 \\
55 \\
37 \\
27 \\
65\end{array}$ \\
\hline $\begin{array}{l}\text { Mean of patients } \\
(4-12)\end{array}$ & 63 & 102 & 175 & 218 & 179 & 138 & 25 & 111 & 118 & 128 & 91 \\
\hline Controls & 55 & 93 & 145 & 141 & 104 & 80 & 18 & 102 & 129 & 85 & 34 \\
\hline$P$ & & NS & 0.05 & 0.001 & 0.001 & 0.01 & NS & NS & NS & NS & 0.01 \\
\hline
\end{tabular}

peak insulin response outwith the normal range for our laboratory (Buchanan \& McKiddie (1967b); the third had a rather low response. In all three the peak insulin level occurred at $30 \mathrm{~min}$.

Most of the nine patients with a mildly abnormal GTT had insulin responses in the upper range of 'normal'; one was very high and one rather low. In only one of these patients did the peak response occur at $30 \mathrm{~min}$, in two it was delayed until $90 \mathrm{~min}$ and in two did not occur until $120 \mathrm{~min}$. The mean insulin response of these nine patients was similar in degree to that of the eight normal subjects of similar age. However, the response was more prolonged in the pancreatic group so that the 120-min value was significantly higher than in the controls $(P<0 \cdot 01)$. The blood sugar levels were significantly higher at all times following oral glucose.

The four patients with frank diabetes mellitus following acute pancreatitis all had a low insulin response to glucose. The one patient in this group with asymptomatic diabetes resembled the chronic pancreatic group in that she had a prolonged insulin response to glucose.

\section{(b) Patients with carcinoma of the pancreas}

These patients all had abnormal glucose tolerance. Six had a low insulin response to glucose; in the remaining two the response was normal in degree but the peak did not occur until $120 \mathrm{~min}$ after glucose (Table 2).

TABLE 2. Plasma insulin response to oral glucose in patients with carcinoma of pancreas

\begin{tabular}{lccccc}
\hline & \multicolumn{5}{c}{ Time after oral glucose* } \\
\cline { 2 - 6 } & $0 \mathrm{~min}$ & $30 \mathrm{~min}$ & $60 \mathrm{~min}$ & $90 \mathrm{~min}$ & $120 \mathrm{~min}$ \\
\hline 1 & 6 & 42 & 43 & 50 & 62 \\
2 & 0 & 34 & 22 & 13 & 17 \\
3 & 15 & 43 & 34 & 21 & 15 \\
4 & 21 & 46 & 55 & 46 & 68 \\
5 & 24 & 34 & 33 & 41 & 37 \\
6 & 20 & 30 & 60 & 35 & 40 \\
7 & 14 & 22 & 0 & 8 & 13 \\
8 & 18 & 18 & 19 & 27 & 18 \\
\hline \multicolumn{5}{c}{} \\
\cline { 2 - 6 } & * Plasma insulin $(\mu \mathrm{U} / \mathrm{ml})$.
\end{tabular}

\section{Discussion}

The finding of low insulin levels in the four patients with symptomatic diabetes in association with pancreatitis is in keeping with the results of Berson \& Yalow (1962) and Peters et al. (1966). However, although the patients of Berson \& Yalow (1962) had severely impaired glucose tolerance, those of Peters et al. (1966) were only mildly abnormal and clinically resembled more closely the ten patients presented here with clinical diabetes in whom there was a prolonged insulin response of normal degree. 
This type of response was also shown in a single case of acute pancreatitis described by Yalow \& Berson (1960). The insulin levels, however, may be low in relation to the associated elevated blood sugars, although similar levels were able to prevent similar hyperglycaemia in the normal subjects.

The prolonged insulin response with, in many cases, a progressive increase in insulin levels up to 120 min, suggests a continuing pancreatic response to a hyperglycaemic load. This type of response has been shown to occur in a number of patients with maturity-onset diabetes mellitus (Yalow \& Berson, 1960; Buchanan \& McKiddie, 1967c). In all three patients with normal glucose tolerance the peak insulin response occurred at $30 \mathrm{~min}$ which may be of significance since it has been suggested (Seltzer \& Allen, 1963) that 'biochemical inertia' of the $\beta$ cell is the primary abnormality in diabetes mellitus.

The results of the present study do not suggest that simple pancreatic deficiency is the cause of the diabetes mellitus which may develop in association with pancreatitis, although it is likely that these patients have impaired reserve (Joffe et al., 1968). However, they are still capable of producing normal or greater than normal insulin levels in response to glucose, and it is interesting that patients with pancreatic disease should develop glucose intolerance in the face of normal plasma insulin levels. One would expect that in pancreatic disease a decrease in insulin levels would first occur, followed by glucose intolerance. The opposite event might suggest that the circulating insulin is in an inactive form, e.g. pro-insulin (Rubenstein, Cho \& Steiner, 1968) or A and B chains (Varandani, 1968) or that the pancreatic disease has disturbed the release mechanism of insulin itself. Another possibility might be that the damaged pancreas releases excessive amounts of insulin antagonists (Ensinck, Mahler \& Vallance-Owen, 1965).

It is possible that these patients had essential diabetes mellitus unrelated to their pancreatic disease, though the proportion with abnormal glucose tolerance seems rather high. Certainly six of them were over 60 years of age and glucose tolerance is known to decline with age.

The finding of abnormal glucose tolerance in carcinoma of the pancreas is common, figures quoted varying from $12-32 \%$ (Salmon, 1966) to $86 \%$ (Dashiell \& Palmer, 1948). All eight patients studied have had abnormal glucose tolerance but all had progressed to the stage of obstructive jaundice, and this alone may impair glucose tolerance (Berkowitz,
Blinkoff \& Glassman, 1966). The low delayed insulin response is in keeping with destruction of the pancreatic islets.

\section{Acknowledgments}

We are grateful to Dr A. H. Imrie and Professor E. M McGirr for continuing help and encouragement in the immunoassay of insulin. We thank Professor W. A. Mackey, Dr W. W. Buchanan, Dr A. Ferguson and Dr J. D. Maxwell for allowing us to study patients under their care.

\section{References}

Banks, S., Jackson, W.P.U., Keller, P. \& Marks, I.N (1968) Serum insulin response to glucose in pancreatic diabetics. Postgrad. med. J. 44, 214.

Berkowitz, D., Blinkoff, B. \& Glassman, S. (1966) Carbohydrate metabolism in jaundice. Gastroenterology, 50, 830

Berson, S.A. \& YAlow, R.S. (1962) Immunoassay of Hormones; Ciba Foundation Colloquia on Endocrinology, Volume 14, p. 182. Churchill, London.

Buchanan, K.D. \& MCKIDdie, M.T. (1967a) Experience with the immuno-precipitation technique of insulin assay with reference to sensitivity, precision and specificity. Clin. chim. Acta, 15, 315.

BuchanaN, K.D. \& MCKIDdie, M.T. (1967b) The norma insulin response to glucose. The relationship between blood sugar and plasma insulin. Diabetologia, 3, 460.

BuchanaN, K.D. \& MCKidDie, M.T. (1967c) Factors determining the plasma insulin response to oral glucose in diabetes mellitus. Diabetes, 16, 466.

Chey, W.Y., Shay, H., Nielsen, O.F. \& LoRher, S.H. (1967)ठ Evaluation of tests of pancreatic function in chronic pancreatic disease. J. Amer. med. Ass. 201, 347.

Dashiell, G.F. \& Palmer, W.H. (1948) Carcinoma of the pancreas, diagnostic criteria. Arch. intern. Med. 81, 173 .

Ensinck, S.W., MahleR, R.S. \& VallanCe-OWen, J. (1965) Antagonism of insulin action on muscle by the albuminbound B chain of insulin. Biochem. J. 94, 150.

Hales, C.N. \& RANDle, P.J. (1963) Immunoassay of insulin with insulin-antibody precipitate. Biochem. J. 88, 137.

JOFFE, B.I., BANK, S., JACKSON, W.P.U., KELLER, P., O'Reilly, I.G. \& VINIK, A.I. (1968) Insulin reserve in patients with chronic pancreatitis. Gut, 7, 277.

Keller, P., BanK, S., Jackson, W.P.U., Marks, I.N. \& O'Reilly, I.G. (1965) Plasma-insulin levels in 'pancreatic diabetes'. Lancet, ii, 1211.

Peters, N., Dick, A.P., Hales, C.N., Orrell, D.H. \& SARNER, M. (1966) Exocrine and endocrine pancreatic function in diabetes mellitus and chronic pancreatitis. Gut, 7, 277.

Rubenstein, A.H., Cho, S. \& Steiner, D.F. (1968) Evidence for pro-insulin in human urine and serum. Lancet, i, 1353.

SALMON, P.A. (1966) Carcinoma of the pancreas and extrahepatic biliary system. Surgery, 60, 554.

Seltzer, H.S. \& Allen, E.W. (1963) Evidence that the primary lesion in diabetes mellitus is biochemical inertia of the beta cell. J. Lab. clin. Med. 62, 1014.

VARANDANI, P.T. (1968) Plasma concentrations of A and B chains of insulin in non-diabetic, diabetic and high risk potential diabetic subjects. Diabetes, $17,547$.

YALOW, R.S. \& BERSON, S.A. (1960) Immunoassay of endogenous plasma insulin in man. J. clin. Invest. 39, 1157. 